\title{
Awareness, Perception and Implementation of Focus Antenatal Care (FANC) among Health Care Providers Working in Mother Care Clinics and Hospitals in Benue State, Nigeria
}

\author{
Article by Emmanuel O. Chukwu' ${ }^{1}$ Terna M. Fiase ${ }^{2}$, Chinyere E. Achukwu ${ }^{3}$, \\ Terhemba P. Valentine ${ }^{4}$ \\ 1, 2, 3 School of Nursing, Mkar Gboko \\ ${ }^{4}$ School of Nursing, Makurdi \\ E-mail: ${ }^{1}$ emmanwaguy42@yahoo.com
}

\begin{abstract}
This non-experimental, cross-sectional descriptive study assessed the "awareness, perception and implementation of focus antenatal care (FANC) among health care providers working in mother care clinics and hospitals in Benue State, Nigeria". The target population comprised all skilled health care providers working in all the mother care clinics and hospitals in Benue State. The sample size consisted of 195 respondents who were selected using the convenient sampling technique after stratified sampling method. The demographic data obtained from the distributed questionnaire were analyzed using pie chart, and bar graph. Data collected were presented in frequency and percentage. Mean scores were used to analyze the data. 2.50 was chosen as the bench mark ( $\geq 2.5$ as criteria of acceptance). Inferential statistics (chi-square) $\left[x^{2}\right]$ was used to test the hypothesis at 0.05 level of significance. Findings revealed that health care providers are aware of FANC in their hospitals/clinics. Result also shows that health workers have positive perception about FANC. The health workers have tried to implement most of the activities under FANC, but some important ones such as assessment for referral, screening and some tests were not properly implemented. There were no major factors militating against the implementation of FANC in hospitals/clinics in Benue State. The hospitals/clinics do not want to implement FANC because it may deter the quantity of visits that contributes to the earning of the hospital/clinics. Hence, they are unwilling neither to implement the recommended four visits of FANC nor to educate the mothers about FANC. Based on the results, the researchers recommend that government should enforce the full implementation of FANC in all the other care hospitals/clinics in Benue State because of its significant impact on the quality care for expectant mothers. Thus, ensures a complication free pregnancy and child birth. The health care providers should implement all other activities under FANC such as assessment for referral, and some important screening and tests as these activities are also very important at ensuring complication free pregnancy and child birth. Health workers should try to educate the mothers on the importance of FANC so that they can embrace it since it has been proven to be the best approach to ANC.
\end{abstract}

Keywords: Awareness, Perception, Implementation, FANC, Skilled, Healthcare, Providers, Nigeria

\section{Introduction}

Antenatal care (ANC) is the care given to a pregnant woman from the time conception is confirmed until the beginning of labour (Marshall and Raynor, 2014; Agboola, 2006; Shaikh, 2016). Such screening program intends to detect early complications; provide health education and implement effective health promotive and preventive interventions (Gaym, 2009). During the antenatal periods, the health care providers especially the midwife provides accessible and relevant information to help the pregnant woman make informed choices throughout pregnancy (Marshall and Raynor, 2014). Antenatal period also provides opportunities for pregnant women to receive prophylactic medications, vaccinations, 
Texila International Journal of Nursing

Volume 3, Issue 1, Mar 2017

diagnosis and treatment of infectious diseases and health education programs (Campbell and Graham, 2006). Emphasis on the quality instead of quantity of visits reflects this new understanding about the role of FANC as further recommended by the World Health Organisation (WHO) (UK Essays, 2016). Health care providers are expected to be fully aware of the FANC model, to develop the skills and awareness on the implementation of the associated activities. Maternal mortality and morbidity have continued to persist in Nigeria. The rates of its decline are slow, because antenatal care services for addressing this problem remain severely underutilized (Funmi, 2014).

Every year, nearly half a million women and girls needlessly die as a result of complications during pregnancy, childbirth or the 6 weeks following delivery. Almost all (99\%) of these deaths occur in developing countries like Nigeria (United Nations, 2009). To prevent these unwanted outcomes of pregnancy, ANC is the most important method for detecting pregnancy problems in the early period. ANC is a critical element for reducing maternal mortality, and for providing pregnant women with a broad range of health promotion and preventive health services (Agus and Horiuchi, 2012). However, health care providers must first be aware and knowledgeable about the current ANC guidelines provided by the WHO. With this, proper implementations of the ANC activities will be carried out. FANC is the modern approach to ANC which ensures quality of services by skilled health care providers as against traditional ANC that emphasizes quantity of visits ((Banda, 2013)). Frequent visits to traditional ANC do not improve pregnancy outcome especially among the developing countries due to logistics and financial concerns. Many women who have risk factors never develop complications, while women without risk factors often do. The implication is that scarce health care resources may be devoted to unnecessary care for "high-risk"- women who never develop complications, and -"low-risk"- women may be unprepared to recognize or respond to signs of complications (Ekabua, Ekabua, and Njoku, 2011). FANC recognizes that every pregnant woman is at risk for complications and should receive the same basic care and monitoring for complications. Hence, the need for every health care provider to embrace the core principles and ensure a timely implementations (Funmi, 2014).

One of the strategies to improve maternal health is the implementation and appropriate use of (FANC) services (Banda, 2013). This strategy promotes pregnant-woman centered care throughout the pregnancy (WHO 2001). Trials conducted in Argentina, Cuba, Saudi Arabia, and Thailand proved that FANC was safe, sustainable, comprehensive, and effective antenatal care (ANC) model (WHO, 2001). Based on the results from numerous studies on FANC, the (WHO) in 2001 issued the implementing guidelines in developing countries. The new FANC model reduces the number of required antenatal visits to four, and provides focused services shown to improve both maternal and neonatal outcomes (Banda, 2013).

\section{Purpose of the study}

The purpose of the study was to assess the awareness, perception and implementation of focus antenatal care (FANC) among health care providers working in mother care clinics and hospitals in Benue state, Nigeria.

\section{Hypotheses}

The following four null hypotheses were tested in this study;

1. Health care providers are not aware of FANC

2. Health care providers prefer traditional ANC to FANC

3. Health care providers does not implement FANC in their hospitals/clinics

4. There are no factors militating against implementation of FANC by health care providers in hospitals/clinics. 


\section{Methodology}

\section{Research design}

This non-experimental, cross-sectional descriptive survey design aimed to assess the awareness, perception, and implementation of FANC among health care providers working in mother care clinics and hospital in Gboko, Benue State, Nigeria. This design is fitting because the study was based on observations that took place in study group at once. Hence, there was neither experimental procedure nor variables been manipulated by the researchers (Glass and Hopkins, 1996).

\section{Setting for the study}

The study was conducted in Benue State Nigeria. Benue State has two major cities Makurdi (the capital) and Gboko, a traditional caliphate of Tiv people. The study was conducted in Gboko city due to the mixture of government, non-governmental and private owned mother care clinics and hospitals than other cities within the State.

\section{Target population}

The target population included all the health care providers working in; (a) government owned or public mother care clinics, primary health care centers, hospitals and maternity (b) private or individual owned mother care clinics, hospitals and maternity (c) non-governmental organizational owned mother care clinics, primary health centers, hospitals and maternity located within Gboko city, Benue State.

\section{Sample and sampling techniques}

Samples were selected from the various target population groups using a convenience sampling technique. The qualifying criteria required for inclusion in the survey was health care providers such as midwives, nurses, doctors, community health extension workers (CHEWS) working in the above context areas. Before using a convenience sampling technique a stratified sampling was used ie the population was divided into homogeneous sub-groups. This step ensured that the representation of all various groups of mother care clinics and hospitals were included in the study. Gboko town has about 25 hospitals/clinics of which 15 hospitals and clinics were selected and surveyed out of which 205 sample.

\section{Instrument for data collection}

A self-designed, structured questionnaire was used for the data collection to achieve the objectives of this study. The questionnaire has introductory part to provide detailed information about researcher, expected outcomes in the participation and instruction on how to answer the research instrument. Section A of the questionnaire has to do with the sociodemographic data of the respondents while section B, C,D,E were designed to answer the research questions. The questionnaire comprised about 30 items that comprised of both open and close ended questions. Some part of the questionnaire consisted of 4-point Likert scale (Strongly Agree $(\mathrm{SA})=4$, Agree $(\mathrm{A})=3$, Disagree $(\mathrm{D})=2$, and Strongly Disagree $(\mathrm{SD})=1$ ).

\section{Data collection}

A total of 205 questionnaires were distributed by the researchers and a trained research assistant to all the health care providers who were selected from various groups of mother care clinics and hospitals in Gboko city, Benue State. However, there were only 195 completed questionnaires used for the analysis that yielded a $95.12 \%$ response rate. The questionnaires were given to the respondents at their various workplaces with a two-day waiting period for the return questionnaire prior to the data analysis.

\section{Method of data analysis}

The demographic data obtained from the distributed questionnaires were analyzed using pie chart, and bar graph. Collected data were presented in frequency and percentage. Mean 
Texila International Journal of Nursing

Volume 3, Issue 1, Mar 2017

scores were used to analyze the data and interpreted as from which $>2.50$ as positive and $<2.50$ as negative. Chi-square $\left(\mathrm{X}^{2}\right)$ was used to test the hypotheses at 0.05 level of significance.

\section{Ethical consideration}

A letter of introduction from the researchers was taken to the directors and in charge of the various mother care institutions requesting for the approval of the study in their institutions. Following the approval, consent was obtained from the respondents prior to the completion of the survey. Respondents were informed that participation was voluntary. Privacy and confidentiality were maintained in getting information from the respondents by demanding for neither the names nor address of the respondents. The researchers ensured that the respondents understood the nature and purpose of the research, and how they will benefit from it.

\section{Data presentation and discussion of findings}

\section{Demographic data of the respondents $(n=195)$}

Data collected from the respondents showed that 100 percent were female because of the common cultural believe that males are not supposed to be working in maternity, antennal and postnatal units of the hospitals. The analysed data also showed that majority of the respondents belonged to 41 and 45 years of age. Results revealed that nurses, midwives and CHEWs who participated were females.

Majority of the respondents were Chief Nursing Officers (CNO) and senior community health extension workers (CHEW). Newly employed health care providers are not normally employed to work in some sensitive units like maternity, antenatal and postnatal units. On the other hand, majority of the respondents had working experience between 26 and 30 years. Long experienced health care providers preferred to work in maternity, antenatal and postnatal units. On the educational qualification, majority were registered nurse $(\mathrm{RN}) /$ registered midwife $(\mathrm{RM})$. The trained and licensed health care providers were the ones rendering health care services in the units of the hospital/clinics been studied. Majority of the respondents were selected from public (government) hospitals/clinics followed by the private and mission-owned hospitals/clinics. This shows that Gboko city have good number of government health institutions.

\section{Awareness level of skilled health care providers on FANC}

Table 1. Level of awareness of health care providers on FANC $(n=195)$

\begin{tabular}{|l|l|l|l|l|l|l|}
\hline No. & Item & SA (\%) & A (\%) & D (\%) & $\begin{array}{l}\text { SD } \\
(\mathbf{\%})\end{array}$ & Mean \\
\hline 1. & You are aware of FANC & $130(66.7)$ & $65(33.3)$ & $0(0)$ & $0(0)$ & 3.67 \\
\hline 2. & $\begin{array}{l}\text { FANC has four visit } \\
\text { approach }\end{array}$ & $145(74.4)$ & $50(25.6)$ & $0(0)$ & $0(0)$ & 3.74 \\
\hline 3 & $\begin{array}{l}\text { FANC emphasizes } \\
\text { quality of care rather } \\
\text { than quantity of visits }\end{array}$ & $45(23.1)$ & $150(76.9)$ & $0(0)$ & $0(0)$ & 3.23 \\
\hline 4. & $\begin{array}{l}\text { Care rendered under } \\
\text { FANC is only by skilled } \\
\text { or trained health care } \\
\text { provider }\end{array}$ & $120(61.5)$ & $75(38.5)$ & $0(0)$ & $0(0)$ & 3.62 \\
\hline 5. & $\begin{array}{l}\text { FANC deal with each } \\
\text { woman specific needs }\end{array}$ & $128(65.6)$ & $65(33.3)$ & $2(1.1)$ & $0(0)$ & 3.65 \\
\hline 6. & $\begin{array}{l}\text { FANC helps in birth } \\
\text { preparedness and } \\
\text { complication planning }\end{array}$ & $145(74.4)$ & $50(25.6)$ & $0(0)$ & $0(0)$ & 3.74 \\
\hline
\end{tabular}




\begin{tabular}{|l|l|l|l|l|l|l|}
\hline 7. & $\begin{array}{l}\text { FANC emphasizes } \\
\text { evidence based and goal } \\
\text { directed actions }\end{array}$ & $45(23.1)$ & $150(76.9)$ & $0(0)$ & $0(0)$ & 3.23 \\
\hline
\end{tabular}

Note $:<2.50$ means negative, $>2.50$ means positive

From table 1 above, all the items in the table have mean scores above 2.50. The cluster mean of 3.55 shows that health care providers were aware of FANC in their hospitals/clinics. This finding is in agreement with study by Ekabua, Ekabua and Njoku (2011) using 200 participants selected from 5 Teaching Hospital in Nigeria which showed high level of awareness $(80 \%)$ of tenets of FANC among resident doctors. This finding of this present study differ from that of Amosu et al (2011) whose study was on the acceptance and practice of focused antenatal care by health care providers in South-east zone of Nigeria using 600 health workers showed that healthcare providers and pregnant women were ignorance about FANC and this was one of the major factors affecting the utilization of FANC. The difference could be as a result of the time in which the study was carried out since new concepts are not easily being disseminated especially in developing country like Nigeria. The time gap since his study was carried out may have been a good reason for the difference.

\section{Perception of health workers on FANC}

Table 2. Perception of health care providers on FANC $(n=195)$

\begin{tabular}{|l|l|l|l|l|l|l|}
\hline No. & Item & SA (\%) & A (\%) & D (\%) & SD (\%) & Mean \\
\hline 1. & $\begin{array}{l}\text { FANC and traditional } \\
\text { ANC offer the same } \\
\text { quality of service and } \\
\text { yield the same result. }\end{array}$ & $0(0)$ & $12(6.2)$ & $110(56.4)$ & $73(37.4)$ & 1.68 \\
\hline 2. & $\begin{array}{l}\text { FANC emphasizes too } \\
\text { much of visit }\end{array}$ & $0(0)$ & $0(0)$ & $61(31.3)$ & $134(68.7)$ & 1.31 \\
\hline 3 & $\begin{array}{l}\text { Women who attend } \\
\text { traditional ANC deliver } \\
\text { easier and do not have } \\
\text { complications. }\end{array}$ & $0(0)$ & $30(15.4)$ & $93(47.7)$ & $72(36.9)$ & 1.63 \\
\hline 4. & $\begin{array}{l}\text { FANC provide more } \\
\text { opportunity in thorough } \\
\text { assessment than } \\
\text { traditional ANC }\end{array}$ & $52(26.7)$ & $130(66.7)$ & $13(6.7)$ & $0(0)$ & 3.18 \\
\hline 5. & $\begin{array}{l}\text { Most women who give } \\
\text { birth in your hospital } \\
\text { attend FANC }\end{array}$ & $0(0)$ & $15(7.7)$ & $150(76.9)$ & $30(15.4)$ & 1.92 \\
\hline 6. & $\begin{array}{l}\text { Mothers are educated on } \\
\text { FANC in your } \\
\text { hospital/clinic }\end{array}$ & $5(2.6)$ & $30(15.4)$ & $110(56.4)$ & $50(25.6)$ & 1.95 \\
\hline Cluster Mean & & & & 1.95 \\
\hline
\end{tabular}

Note $:<2.50$ means negative, $>2.50$ means positive

From table 2 above, almost all the items in the table have mean scores below 2.50. The cluster mean of 1.95 shows that health care providers have positive perception about FANC. This finding is in agreement with that of Yengo (2009) whose study on nurses' perception about the implementation of focused antenatal care services in Tanzania using 143 nurses showed that nurses viewed FANC as beneficial to women and their perception did not affect implementation of FANC. 
Texila International Journal of Nursing

Volume 3, Issue 1, Mar 2017

\section{Implementation of FANC among health care providers}

Table3a. Implementation of FANC by health care providers (1st visit).(n=195)

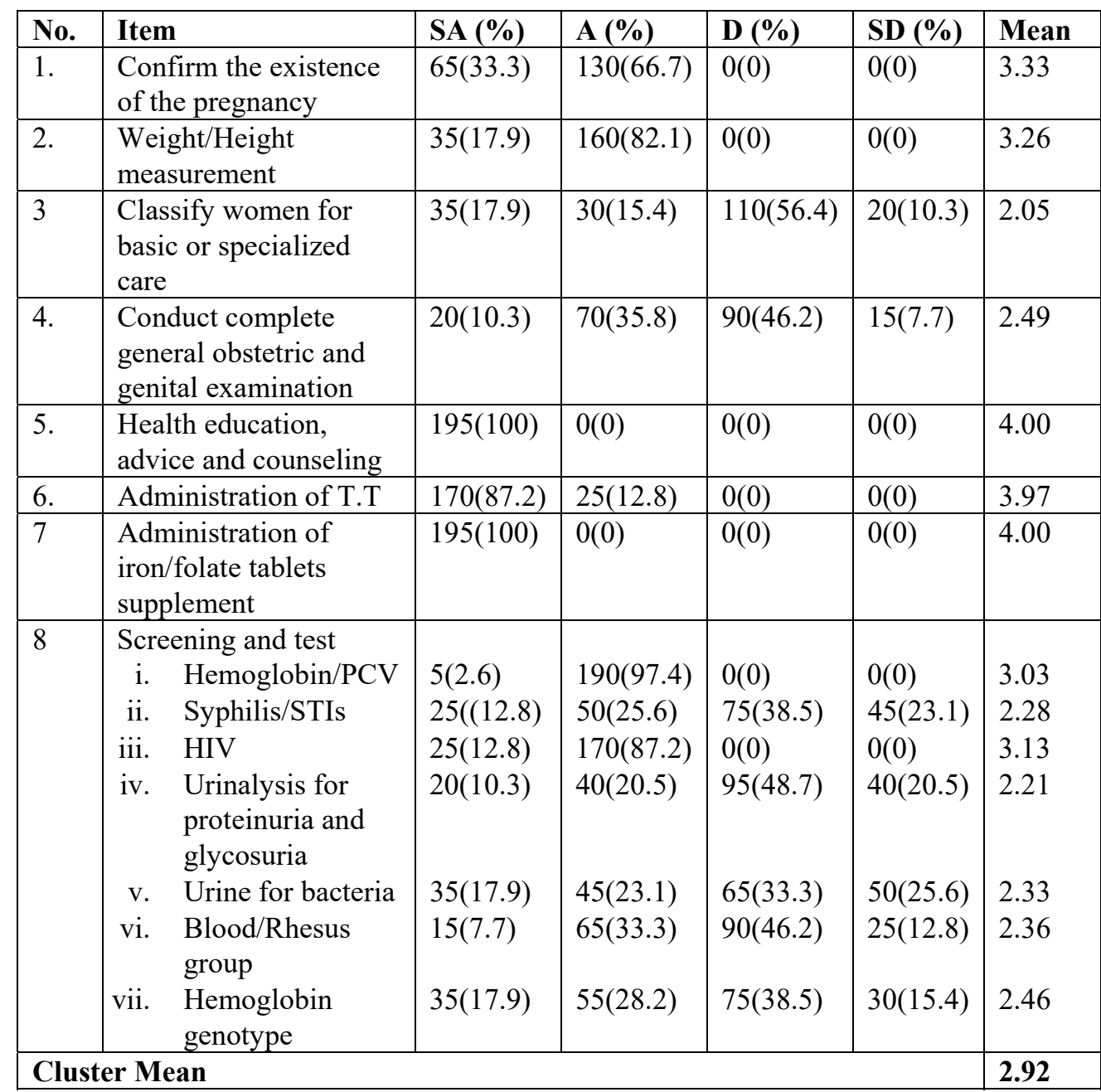

Note $:<2.50$ means negative, $>2.50$ means positive

Table $3 \mathrm{a}$ above shows that some of the items have mean scores above 2.50 while others have mean score below 2.50. The Cluster mean of 2.92 shows that health care providers have implemented majority of the activities needed under first visit.

Table 3b. Implementation of FANC by health care providers $\left(2^{\text {nd }}\right.$ visit $) .(n=195)$

\begin{tabular}{|l|l|l|l|l|l|l|}
\hline No. & Item & SA (\%) & A (\%) & D (\%) & SD (\%) & Mean \\
\hline 1. & Check BP & $160(82.1)$ & $35(17.9)$ & $0(0)$ & $0(0)$ & 3.82 \\
\hline 2. & $\begin{array}{l}\text { Check for signs of } \\
\text { anaemia }\end{array}$ & $150(76.9)$ & $45(23.1)$ & $0(0)$ & $0(0)$ & 3.77 \\
\hline 3 & $\begin{array}{l}\text { Check fetal growth and } \\
\text { well-being }\end{array}$ & $5(2.6)$ & $190(97.4)$ & $0(0)$ & $0(0)$ & 3.03 \\
\hline 4. & $\begin{array}{l}\text { Screening and tests } \\
\text { i. } \quad \begin{array}{l}\text { Urine for } \\
\text { bacteriauria }\end{array}\end{array}$ & $120(61.5)$ & $75(38.5)$ & $0(0)$ & $0(0)$ & 3.62 \\
$\begin{array}{l}\text { ii. } \quad \begin{array}{l}\text { Urinalysis for } \\
\text { proteinuria in } \\
\text { primigravida } \\
\text { Hemoglobin/PCV }\end{array} \\
\text { iii. }\end{array}$ & $35(17.9)$ & $47(24.1)$ & $75(38.5)$ & $38(19.5)$ & 2.41 \\
\hline
\end{tabular}




\begin{tabular}{|l|l|l|l|l|l|l|} 
& \multicolumn{1}{|c|}{ for anemia } & & & & \\
\hline 5. & $\begin{array}{l}\text { Administration of } 2^{\text {nd }} \\
\text { dose of T.T }\end{array}$ & $195(100)$ & $0(0)$ & $0(0)$ & $0(0)$ & 4.00 \\
\hline 6. & $\begin{array}{l}\text { Administration of ARV } \\
\text { therapy if indicated }\end{array}$ & $160(82.1)$ & $35(17.9)$ & $0(0)$ & $0(0)$ & 3.82 \\
\hline 7. & $\begin{array}{l}\text { Administration of } \\
\text { antibiotics for bacteriauria } \\
\text { if indicated }\end{array}$ & $15(7.7)$ & $180(90.9)$ & $0(0)$ & $0(0)$ & 3.08 \\
\hline 8. & $\begin{array}{l}\text { Administration of } \\
\text { anthelminthic for worms }\end{array}$ & $0(0)$ & $15(7.7)$ & $120(61.5)$ & $60(30.8)$ & 1.77 \\
\hline 9 & $\begin{array}{l}\text { Administration of } \\
\text { iron/folate tablets }\end{array}$ & $195(100)$ & $0(0)$ & $0(0)$ & $0(0)$ & 4.00 \\
\hline 10 & $\begin{array}{l}\text { Administration of } 1^{\text {st }} \text { dose } \\
\text { of antimalarial using SP }\end{array}$ & $15(7.7)$ & $180(90.9)$ & $0(0)$ & $0(0)$ & 3.08 \\
\hline 11 & $\begin{array}{l}\text { Health education, advise } \\
\text { and counseling }\end{array}$ & $195(100)$ & $0(0)$ & $0(0)$ & $0(0)$ & 4.00 \\
\hline
\end{tabular}

Note $:<2.50$ means negative, $>2.50$ means positive

From table $3 \mathrm{~b}$ above, almost all the items in the table have mean scores above 2.50 . The cluster mean of 3.35 shows that the health workers have implemented most of the activities needed during the second visit.

Table 3c. Implementation of FANC by health care providers ( $3^{\text {rd }}$ visit). $(\mathrm{n}=195)$

\begin{tabular}{|l|l|l|l|l|l|l|}
\hline No. & Item & SA (\%) & A (\%) & D (\%) & SD (\%) & Mean \\
\hline 1. & Check BP & $150(76.9)$ & $45(23.1)$ & $0(0)$ & $0(0)$ & 3.77 \\
\hline 2. & $\begin{array}{l}\text { Check for signs of } \\
\text { aneamia }\end{array}$ & $150(76.9)$ & $45(23.1)$ & $0(0)$ & $0(0)$ & 3.77 \\
\hline 3 & $\begin{array}{l}\text { Check fetal growth and } \\
\text { wellbeing }\end{array}$ & $70(35.8)$ & $125(64.1)$ & $0(0)$ & $0(0)$ & 3.36 \\
\hline 4. & $\begin{array}{l}\text { Administration of ARV } \\
\text { therapy if indicated }\end{array}$ & $195(100)$ & $0(0)$ & $0(0)$ & $0(0)$ & 4.00 \\
\hline 5. & $\begin{array}{l}\text { Administration of } \\
\text { antibiotics for } \\
\text { bacteriuria if indicated }\end{array}$ & $95(48.7)$ & $100(51.3)$ & $0(0)$ & $0(0)$ & 3.49 \\
\hline 6. & $\begin{array}{l}\text { Administration of 2 } \\
\text { dose of T.T }\end{array}$ & $170(87.2)$ & $25(12.8)$ & $0(0)$ & $0(0)$ & 3.87 \\
\hline 7. & $\begin{array}{l}\text { Administration of 2nd } \\
\text { dose of antimalarial } \\
\text { using SP }\end{array}$ & $160(82.1)$ & $35(17.9)$ & $0(0)$ & $0(0)$ & 3.82 \\
\hline 8 & $\begin{array}{l}\text { Health education, } \\
\text { advice and counseling }\end{array}$ & $195(100)$ & $0(0)$ & $0(0)$ & $0(0)$ & 4.00 \\
\hline 9. & $\begin{array}{l}\text { Screening and tests } \\
\text { i. Urine for } \\
\text { bacteriuria } \\
\text { ii. Urinalysis for } \\
\text { proteinuria in } \\
\text { primigravida }\end{array}$ & $25(12.8)$ & $55(28.2)$ & $55(28.2)$ & $60(30.8)$ & 2.23 \\
\hline Cluster Mean & $15(7.7)$ & $35(17.9)$ & $85(43.6)$ & $60(30.8)$ & 2.06 \\
\hline
\end{tabular}

Note $:<2.50$ means negative, $>2.50$ means positive

Table $3 \mathrm{c}$ above shows that most of the items in the table have mean scores above 2.50 . The cluster mean of 3.44 shows that the health workers have implemented most of the activities needed during $3^{\text {rd }}$ visit. 
Texila International Journal of Nursing

Volume 3, Issue 1, Mar 2017

Table 3d. Implementation of FANC by health care providers ( $4^{\text {th }}$ visit $)(n=195)$

\begin{tabular}{|c|c|c|c|c|c|c|}
\hline No. & Item & SA (\%) & A (\%) & $\begin{array}{l}\text { D } \\
(\%)\end{array}$ & SD (\%) & Mean \\
\hline 1. & $\begin{array}{l}\text { General physical } \\
\text { examination }\end{array}$ & $55(28.2)$ & $140(71.8)$ & $0(0)$ & $0(0)$ & 3.28 \\
\hline 2. & Measure BP & $150(76.9)$ & $45(23.1)$ & $0(0)$ & $0(0)$ & 3.77 \\
\hline 3 & Measure fundal height & $170(87.2)$ & $25(12.8)$ & $0(0)$ & $0(0)$ & 3.87 \\
\hline 4. & $\begin{array}{l}\text { Palpate abdomen for } \\
\text { fetal lie and } \\
\text { presentation as well as } \\
\text { for twins and breech }\end{array}$ & $160(82.1)$ & $35(17.9)$ & $0(0)$ & $0(0)$ & 3.82 \\
\hline 5 . & $\begin{array}{l}\text { Review and } \\
\text { modification of birth } \\
\text { and emergency plan }\end{array}$ & $15(7.7)$ & $33(16.9)$ & $\begin{array}{l}88(45 . \\
1)\end{array}$ & $59(30.3)$ & 2.02 \\
\hline 6. & Assess for referral & $10(5.1)$ & $50(25.6)$ & $\begin{array}{l}120(6 \\
1.5)\end{array}$ & $15(7.7)$ & 2.28 \\
\hline 7. & $\begin{array}{l}\text { Administration of } \\
\text { iron/folate tablets }\end{array}$ & $195(100)$ & $0(0)$ & $0(0)$ & $0(0)$ & 4.00 \\
\hline 8. & $\begin{array}{l}\text { Administration of } \\
\text { malaria prophylaxis }\end{array}$ & $120(61.5)$ & $75938.5)$ & $0(0)$ & $0(0)$ & 3.62 \\
\hline 9. & Enforce use of LLINS & 195(100) & $0(0)$ & $0(0)$ & $0(0)$ & 4.00 \\
\hline 10. & $\begin{array}{l}\text { Administration of } \\
\text { ARV therapy if } \\
\text { indicated }\end{array}$ & $195(100)$ & $0(0)$ & $0(0)$ & $0(0)$ & 4.00 \\
\hline 11. & $\begin{array}{l}\text { Administration of } \\
\text { antibiotics for } \\
\text { bacteriuria if indicated }\end{array}$ & $35(17.9)$ & $160(82.10)$ & $0(0)$ & $0(0)$ & 3.12 \\
\hline 12. & Screening/Test & & & & & \\
\hline & $\begin{array}{ll}\text { i. } & \text { Test for } \\
& \text { proteinuria in } \\
\text { nullipara }\end{array}$ & $10(5.1)$ & $25(12.8)$ & $\begin{array}{l}85(43 . \\
6)\end{array}$ & $75(38.5)$ & 1.85 \\
\hline & $\begin{array}{ll}\text { ii. } & \begin{array}{l}\text { Screen for } \\
\text { preeclampsia }\end{array} \\
\end{array}$ & $10(5.1)$ & $30(15.4)$ & $\begin{array}{l}80(41 . \\
0)\end{array}$ & $75(38.5)$ & 1.87 \\
\hline 13 & $\begin{array}{l}\text { Health education, } \\
\text { advise and counseling }\end{array}$ & $195(100)$ & $0(0)$ & $0(0)$ & $0(0)$ & 4.00 \\
\hline \multicolumn{6}{|c|}{ Cluster Mean } & 3.25 \\
\hline
\end{tabular}

Note $:<2.50$ means negative, $>2.50$ means positive

From table $3 \mathrm{~d}$ above majority of the items have mean scores above 2.50. Cluster mean of 3.25 shows that the health care providers have implemented most of the activities needed for fourth visit.

This finding shows that the health care providers are trying at implementing some of the activities as required under FANC but are failing to implement some. The efforts is quite commendable, however every efforts should be made to ensure that the remaining activities that are not being implemented are also being implemented because these non-implemented activities are also very important at ensuring that full gain of FANC is derived.

In a similar vein, Conrad et al (2011) showed that health workers working in health facilities in Burkuna Faso, Uganda and Tanzania performed most of the procedures but also omitted certain practices stipulated in the FANC guidelines. Gross, Schellenberg, Kessy, Pfeiffer and Obrist (2011) examined the antenatal care practice in selected clinics situated in Kilombero Valley, South-Eastern Tanzania. Result showed that some recommended services of focused antenatal care guidelines were given to all women while other services were not. Similarly, Boller et al (2003) assessed the quality of care in public and private ANC clinics in 
Dar es Salaam, which found that guidelines were frequently not respected and diagnostic examinations were not carried out by health workers.

\section{Factors militating against FANC}

Table 4. Factors militating against implementation of FANC $(n=195)$

\begin{tabular}{|l|l|l|l|l|l|l|}
\hline No. & Item & SA (\%) & A (\%) & D (\%) & SD (\%) & Mean \\
\hline 1. & $\begin{array}{l}\text { Skilled health providers are } \\
\text { not aware of FANC }\end{array}$ & $0(0)$ & $27(13.8)$ & $70(35.8)$ & $98(50.3)$ & 1.64 \\
\hline 2. & $\begin{array}{l}\text { There are no facilities for } \\
\text { FANC in the hospital/clinic }\end{array}$ & $25(12.8)$ & $30(15.4)$ & $120(61.5)$ & $20(10.3)$ & 2.31 \\
\hline 3 & $\begin{array}{l}\text { There are inadequate } \\
\text { skilled health personnels to } \\
\text { implement FANC }\end{array}$ & $15(7.7)$ & $100(51.3)$ & $30(15.4)$ & $50(25.6)$ & 2.41 \\
\hline 4. & $\begin{array}{l}\text { Your hospital/clinic does } \\
\text { not want FANC }\end{array}$ & $20(10.3)$ & $150(76.9)$ & $10(5.1)$ & $15(7.7)$ & 2.90 \\
\hline 5. & $\begin{array}{l}\text { Mothers prefer traditional } \\
\text { ANC to FANC }\end{array}$ & $60(30.8)$ & $115(59.0)$ & $15(7.7)$ & $5(2.6)$ & 3.18 \\
\hline 6. & $\begin{array}{l}\text { There is } \\
\text { corruption/diversion of } \\
\text { funds meant for FANC } \\
\text { implementation }\end{array}$ & $5(2.6)$ & $60(30.8)$ & $100(51.3)$ & $30(15.4)$ & 2.21 \\
\hline
\end{tabular}

Note $:<2.50$ means negative, $>2.50$ means positive

Table 4 above shows that most of the items in the table have mean scores below 2.50 .

The cluster mean score of 2.45 shows that there are no factors militating against implementation of FANC in hospitals/clinics in Benue State rather the hospitals/clinics does not want to implement FANC. Additional information from the respondents showed that hospitals and clinics in Benue does not want to implement FANC because quantity of visits by the consumers of ANC earns the hospitals and clinics more money.

Conrad et al (2011) conducted a study using a descriptive systematic observation of 788 ANC sessions and service providers which showed that services providers non-compliance of procedures in FANC guidelines was one of the factors contributing to low utilization of FANC.

\section{Testing of hypothesis}

Hypothesis one: Health care providers are not aware of FANC

Table 5. Chi-square $\left(x^{2}\right)$ test on level of awareness of skilled health providers on FANC

\begin{tabular}{|l|l|l|l|l|}
\hline $\mathbf{O}$ & $\mathbf{E}$ & $(\mathbf{O}-\mathbf{E})$ & $(\mathbf{O}-\mathbf{E})^{\mathbf{2}}$ & $\frac{(\boldsymbol{O}-\boldsymbol{E})^{\mathbf{2}}}{\boldsymbol{E}}=\boldsymbol{x}^{\mathbf{2}}$ \\
\hline 130 & 108.3 & 21.7 & 470.89 & 4.35 \\
\hline 65 & 86.4 & -21.4 & 457.96 & 5.30 \\
\hline 0 & 0.3 & -0.3 & 0.09 & 0.30 \\
\hline 0 & 0.0 & 0.0 & 0.00 & 0.00 \\
\hline 145 & 108.3 & 36.7 & 1346.89 & 12.44 \\
\hline 50 & 86.4 & -36.4 & 1324.96 & 15.34 \\
\hline 0 & 0.3 & -0.3 & 0.09 & 0.30 \\
\hline 0 & 0.0 & 0.0 & 0.00 & 0.00 \\
\hline 45 & 108.3 & -63.3 & 4000.89 & 37.00 \\
\hline 150 & 86.4 & 63.6 & 4044.96 & 46.82 \\
\hline 0 & 0.3 & -0.3 & 0.09 & 0.30 \\
\hline 0 & 0.0 & 0.0 & 0.00 & 0.00 \\
\hline
\end{tabular}


Texila International Journal of Nursing

Volume 3, Issue 1, Mar 2017

\begin{tabular}{|l|l|l|l|l|}
\hline 120 & 108.3 & 11.7 & 136.89 & 1.26 \\
\hline 75 & 86.4 & -11.4 & 129.96 & 1.50 \\
\hline 0 & 0.3 & -0.3 & 0.09 & 0.30 \\
\hline 0 & 0.0 & 0.0 & 0.00 & 0.00 \\
\hline 128 & 108.3 & 19.7 & 388.09 & 3.58 \\
\hline 65 & 86.4 & -21.4 & 457.96 & 5.30 \\
\hline 2 & 0.3 & 1.7 & 2.89 & 9.63 \\
\hline 0 & 0.0 & 0.0 & 0.00 & 0.00 \\
\hline 145 & 108.3 & 36.7 & 1346.89 & 12.44 \\
\hline 50 & 86.4 & -36.4 & 1324.96 & 15.34 \\
\hline 0 & 0.3 & -0.3 & 0.09 & 0.30 \\
\hline 0 & 0.0 & 0.0 & 0.00 & 0.00 \\
\hline 45 & 108.3 & -63.3 & 4006.89 & 37.00 \\
\hline 150 & 86.4 & 63.6 & 4044.96 & 46.82 \\
\hline 0 & 0.3 & -0.3 & 0.09 & 0.30 \\
\hline 0 & 0.0 & 0.0 & 0.00 & 0.00 \\
\hline Total & & & $\mathbf{2 5 5 . 9 2}$ \\
\hline
\end{tabular}

The calculated chi-square $\left(x^{2}\right)$ value is 255.92

The tabulated chi-square $\left(x^{2}\right)$ value is 25.99

Since the Chi-square $\left(x^{2}\right)$ test (calculated) $=96.28$ is greater than the tabulated value $=16.92$. There is therefore no statistical evidence to accept the null hypothesis (Ho).This means that the health care providers are fully aware of FANC in their hospitals/clinics.

Hypothesis two: Health care providers prefer Traditional ANC to FANC

Table 6. Chi-square $\left(x^{2}\right)$ test on health care provider of preference of traditional ANC to FANC

\begin{tabular}{|c|c|c|c|c|}
\hline $\mathbf{O}$ & $\mathbf{E}$ & (O-E) & $(\mathrm{O}-\mathrm{E})^{2}$ & $\frac{(O-E)^{2}}{E}=x^{2}$ \\
\hline 0 & 95.0 & -95.0 & 9025.00 & 95.00 \\
\hline 12 & 36.2 & -24.2 & 585.64 & 16.18 \\
\hline 110 & 89.5 & 40.5 & 1640.25 & 18.32 \\
\hline 73 & 59.8 & 13.2 & 174.24 & 2.91 \\
\hline 0 & 95.0 & -95.0 & 9025.00 & 95.00 \\
\hline 0 & 36.2 & -36.2 & 1310.44 & 36.20 \\
\hline 61 & 89.5 & -28.5 & 812.25 & 9.08 \\
\hline 134 & 59.8 & 74.2 & 5505.64 & 92.06 \\
\hline 0 & 95.0 & -95.0 & 9025.00 & 95.00 \\
\hline 30 & 36.2 & -6.2 & 38.44 & 1.06 \\
\hline 93 & 89.5 & 3.5 & 12.25 & 0.14 \\
\hline 72 & 59.8 & 12.2 & 148.84 & 2.49 \\
\hline 52 & 95.0 & -4.3 & 18.49 & 0.19 \\
\hline 130 & 36.2 & 93.8 & 8798.44 & 243.05 \\
\hline 13 & 89.5 & -76.5 & 5852.25 & 65.39 \\
\hline 0 & 59.8 & -59.8 & 3576.04 & 59.80 \\
\hline 0 & 95.0 & -95.0 & 9025.00 & 95.00 \\
\hline 15 & 36.2 & -23.2 & 538.24 & 14.87 \\
\hline 150 & 89.5 & 60.2 & 3624.04 & 40.49 \\
\hline 30 & 59.8 & -29.8 & 888.04 & 14.85 \\
\hline 5 & 95.0 & -90.0 & 8100.00 & 85.26 \\
\hline 30 & 36.2 & -6.2 & 38.44 & 1.06 \\
\hline 110 & 89.5 & 20.5 & 420.25 & 4.70 \\
\hline 50 & 59.8 & -9.8 & 96.04 & 1.61 \\
\hline \multicolumn{4}{|c|}{ Total } & 1089.71 \\
\hline
\end{tabular}


Texila International Journal of Nursing

Volume 3, Issue 1, Mar 2017

The calculated chi-square $\left(x^{2}\right)$ value is 1089.71

The tabulated chi-square $\left(x^{2}\right)$ value is 25.00

Since the Chi-square $\left(x^{2}\right)$ test (calculated) $=1089.71$ is greater than the tabulated value $=25.00$. There is therefore no statistical evidence to accept the null hypothesis (Ho).This means that the health care providers do not prefer traditional ANC to FANC.

Hypothesis three: Health care provider does not implement FANC in their hospitals/clinics.

Table 7. Chi-square $\left(x^{2}\right)$ test for health care providers and implementation of FANC in hospitals/clinic (first visit).

\begin{tabular}{|l|l|l|l|l|}
\hline $\mathbf{O}$ & $\mathbf{E}$ & $\mathbf{( O - E )}$ & $(\mathbf{O}-\mathbf{E})^{\mathbf{2}}$ & $\frac{(\boldsymbol{O}-\boldsymbol{E})^{2}}{\boldsymbol{E}}=\boldsymbol{x}^{\mathbf{2}}$ \\
\hline 65 & 62.5 & 25 & 625.00 & 10.00 \\
\hline 130 & 73.6 & 56.4 & 3180.96 & 43.22 \\
\hline 0 & 42.9 & -42.9 & 1840.41 & 42.90 \\
\hline 0 & 16.1 & -16.1 & 259.21 & 16.10 \\
\hline 35 & 62.5 & -27.5 & 756.25 & 12.10 \\
\hline 160 & 73.6 & 86.4 & 7464.96 & 101.43 \\
\hline 0 & 42.9 & -42.9 & 1840.41 & 42.90 \\
\hline 0 & 16.1 & -16.1 & 259.21 & 16.10 \\
\hline 35 & 62.5 & -27.5 & 756.25 & 12.10 \\
\hline 30 & 73.6 & -43.6 & 1900.96 & 25.83 \\
\hline 110 & 42.9 & 67.1 & 4502.41 & 104.95 \\
\hline 20 & 16.1 & 3.9 & 15.21 & 0.94 \\
\hline 20 & 62.5 & -42.5 & 1806.25 & 28.90 \\
\hline 70 & 73.6 & -3.6 & 12.96 & 0.18 \\
\hline 90 & 42.9 & 47.1 & 2218.41 & 51.71 \\
\hline 15 & 16.1 & -1.1 & 1.21 & 0.08 \\
\hline 195 & 62.5 & 132.5 & 17556.25 & 280.90 \\
\hline 0 & 73.6 & -73.6 & 5416.96 & 73.60 \\
\hline 0 & 42.9 & -42.9 & 1840.41 & 42.90 \\
\hline 0 & 16.1 & -16.1 & 259.21 & 16.10 \\
\hline 170 & 62.5 & 107.5 & 11556.25 & 184.90 \\
\hline 25 & 73.6 & -48.6 & 2361.96 & 32.09 \\
\hline 0 & 42.9 & -42.9 & 1840.41 & 42.90 \\
\hline 0 & 16.1 & -16.9 & 259.21 & 16.10 \\
\hline 195 & 62.5 & 132.5 & 17556.25 & 280.90 \\
\hline 0 & 73.6 & -73.6 & 5416.96 & 73.60 \\
\hline 0 & 42.9 & -42.9 & 1840.41 & 42.90 \\
\hline 0 & 16.1 & -16.1 & 259.21 & 16.10 \\
\hline 5 & 62.5 & -57.5 & 3306.25 & 52.90 \\
\hline 190 & 73.6 & 116.4 & 13548.96 & 184.10 \\
\hline 0 & 42.9 & -42.9 & 1840.41 & 42.90 \\
\hline 0 & 16.1 & -16.1 & 259.21 & 16.10 \\
\hline 25 & 62.5 & -37.5 & 1406.25 & 22.50 \\
\hline 50 & 73.6 & -23.6 & 556.96 & 7.57 \\
\hline 75 & 42.9 & 32.1 & 1030.41 & 24.02 \\
\hline 45 & 16.1 & 28.9 & 835.21 & 51.88 \\
\hline 25 & 62.5 & -37.5 & 1406.25 & 22.50 \\
\hline 170 & 73.6 & 96.4 & 9292.96 & 126.26 \\
\hline 0 & 42.9 & -42.9 & 1840.41 & 42.90 \\
\hline 0 & 16.1 & -16.1 & 259.21 & 16.10 \\
\hline 20 & 62.5 & -42.5 & 1806.25 & 28.90 \\
\hline & & & & \\
\hline
\end{tabular}


Texila International Journal of Nursing Volume 3, Issue 1, Mar 2017

\begin{tabular}{|l|l|l|l|l|}
\hline 40 & 73.6 & -33.6 & 1128.96 & 15.34 \\
\hline 95 & 42.9 & 53.1 & 2819.61 & 65.73 \\
\hline 40 & 16.1 & 23.9 & 571.21 & 35.48 \\
\hline 35 & 62.5 & -27.5 & 756.25 & 12.10 \\
\hline 45 & 73.6 & -28.6 & 817.96 & 11.11 \\
\hline 65 & 42.9 & 22.1 & 488.41 & 11.38 \\
\hline 50 & 16.1 & 33.9 & 1149.21 & 71.38 \\
\hline 15 & 62.5 & -47.5 & 2256.25 & 36.10 \\
\hline 65 & 73.6 & -8.6 & 73.96 & 1.04 \\
\hline 90 & 42.9 & 47.9 & 2294.41 & 53.48 \\
\hline 25 & 16.1 & 8.9 & 79.21 & 4.92 \\
\hline 35 & 62.5 & -27.5 & 756.25 & 12.10 \\
\hline 55 & 73.6 & -18.6 & 345.96 & 4.70 \\
\hline 75 & 42.9 & 32.1 & 1030.41 & 24.02 \\
\hline 30 & 16.1 & 13.9 & 193.21 & 12.00 \\
\hline Total & & $\mathbf{2 6 2 1 . 9 4}$ \\
\hline
\end{tabular}

Table 8. Chi-square $\left(x^{2}\right)$ test for health care providers and implementation of FANC in hospitals/clinic (Second Visit).

\begin{tabular}{|c|c|c|c|c|}
\hline $\mathbf{O}$ & $\mathbf{E}$ & (O-E) & $(\mathrm{O}-\mathrm{E})^{2}$ & $\frac{(O-E)^{2}}{E}=x^{2}$ \\
\hline 160 & 96.2 & 63.8 & 4070.44 & 42.31 \\
\hline 35 & 76.5 & $\begin{array}{l}- \\
41.5\end{array}$ & 1722.25 & 22.51 \\
\hline 0 & 15.0 & -15.0 & 225.00 & 15.00 \\
\hline 0 & 7.5 & -7.5 & 56.25 & 7.50 \\
\hline 150 & 96.2 & 53.2 & 2894.44 & 30.09 \\
\hline 45 & 76.5 & -31.5 & 992.25 & 12.97 \\
\hline 0 & 15.0 & -15.0 & 225.00 & 15.00 \\
\hline 0 & 7.5 & -7.5 & 56.25 & 7.50 \\
\hline 5 & 96.2 & -91.2 & 8317.44 & 86.45 \\
\hline 190 & 76.5 & 113.5 & 12882.25 & 168.40 \\
\hline 0 & 15.0 & -15.0 & 225.00 & 15.00 \\
\hline 0 & 7.5 & -7.5 & 56.25 & 7.50 \\
\hline 120 & 96.2 & 23.8 & 566.44 & 5.89 \\
\hline 75 & 76.5 & -1.5 & 2.25 & 0.02 \\
\hline 0 & 15.0 & -15.0 & 225.00 & 15.00 \\
\hline 0 & 7.5 & -7.5 & 56.25 & 7.50 \\
\hline 35 & 96.2 & -41.4 & 1722.25 & 22.51 \\
\hline 47 & 76.5 & -29.1 & 870.25 & 11.38 \\
\hline 75 & 15.0 & 60 & 3600.00 & 240.00 \\
\hline 38 & 7.5 & 30.5 & 930.25 & 124.03 \\
\hline 5 & 96.2 & -91.2 & 8317.44 & 86.46 \\
\hline 190 & 76.5 & 113.5 & 12882.25 & 168.40 \\
\hline 0 & 15.0 & -15.0 & 225.00 & 15.00 \\
\hline 0 & 7.5 & -7.5 & 56.25 & 7.50 \\
\hline 195 & 96.2 & 98.2 & 9761.44 & 101.47 \\
\hline 0 & 76.5 & -76.5 & 5852.25 & 76.50 \\
\hline 0 & 15.0 & -15.0 & 225.25 & 15.00 \\
\hline 0 & 7.5 & -7.5 & 56.25 & 7.50 \\
\hline 160 & 96.2 & 63.8 & 4070.44 & 42.31 \\
\hline 35 & 76.5 & -41.5 & 1722.25 & 22.51 \\
\hline
\end{tabular}


Texila International Journal of Nursing Volume 3, Issue 1, Mar 2017

\begin{tabular}{|l|l|l|l|l|}
\hline 0 & 15.0 & -15.0 & 225.00 & 15.00 \\
\hline 0 & 7.5 & -7.5 & 56.25 & 7.50 \\
\hline 15 & 96.2 & -81.2 & 6593.44 & 68.54 \\
\hline 180 & 76.5 & 103.5 & 10712.25 & 140.03 \\
\hline 0 & 15.0 & -15.0 & 225.00 & 15.00 \\
\hline 0 & 7.5 & -7.5 & 56.25 & 7.50 \\
\hline 0 & 96.2 & -96.2 & 9254.44 & 96.20 \\
\hline 15 & 76.5 & -61.5 & 3782.25 & 49.44 \\
\hline 120 & 15.0 & 105.0 & 11025.00 & 735.00 \\
\hline 60 & 7.5 & 52.5 & 2756.25 & 367.50 \\
\hline 195 & 96.2 & 98.2 & 9761.44 & 101.47 \\
\hline 0 & 76.5 & -76.5 & 5852.25 & 76.50 \\
\hline 0 & 15.0 & -15.0 & 225.00 & 15.00 \\
\hline 0 & 7.5 & -7.5 & 56.25 & 7.50 \\
\hline 15 & 96.2 & -81.2 & 6593.44 & 68.54 \\
\hline 180 & 76.5 & 103.5 & 10712.25 & 140.03 \\
\hline 0 & 15.0 & -15.0 & 225.00 & 15.00 \\
\hline 0 & 7.5 & -7.5 & 56.25 & 7.50 \\
\hline 195 & 96.2 & 98.2 & 9761.44 & 101.47 \\
\hline 0 & 76.5 & -76.5 & 5852.25 & 76.50 \\
\hline 0 & 15.0 & -15.0 & 225.00 & 15.00 \\
\hline 0 & 7.5 & -7.5 & 56.25 & 7.50 \\
\hline Total & & & $\mathbf{3 5 3 2 . 9 3}$ \\
\hline
\end{tabular}

Table 9. Chi-square $\left(x^{2}\right)$ test for health care providers and implementation of FANC in hospitals/clinic (Third Visit).

\begin{tabular}{|l|l|l|l|l|}
\hline $\mathbf{O}$ & $\mathbf{E}$ & $\mathbf{( O - E )}$ & $(\mathbf{O}-\mathbf{E})^{\mathbf{2}}$ & $\frac{(\boldsymbol{O}-\boldsymbol{E})^{2}}{\boldsymbol{E}}=\boldsymbol{x}^{\mathbf{2}}$ \\
\hline 150 & 122.5 & 27.5 & 756.25 & 6.17 \\
\hline 45 & 46.5 & -1.5 & 2.25 & 0.04 \\
\hline 0 & 14.0 & -14.0 & 196.00 & 14.00 \\
\hline 0 & 12.0 & -12.0 & 144.00 & 12.00 \\
\hline 150 & 122.5 & 27.5 & 756.25 & 6.17 \\
\hline 45 & 46.5 & -1.5 & 2.25 & 0.04 \\
\hline 0 & 14.0 & -14.0 & 196.00 & 14.00 \\
\hline 0 & 12.0 & -12.0 & 144.00 & 12.00 \\
\hline 70 & 122.5 & -52.0 & 2756.25 & 22.5 \\
\hline 125 & 46.5 & 78.5 & 6162.25 & 132.52 \\
\hline 0 & 14.0 & -14.0 & 196.00 & 14.00 \\
\hline 0 & 12.0 & -12.0 & 144.00 & 12.00 \\
\hline 195 & 122.5 & 72.5 & 5256.25 & 42.91 \\
\hline 0 & 46.5 & -46.5 & 2162.25 & 46.50 \\
\hline 0 & 14.0 & -14.0 & 196.00 & 14.00 \\
\hline 0 & 12.0 & -12.0 & 144.00 & 12.00 \\
\hline 95 & 122.5 & -27.5 & 756.25 & 6.17 \\
\hline 100 & 46.5 & 53.5 & 2862.25 & 61.55 \\
\hline 0 & 14.0 & -14.0 & 196.00 & 14.00 \\
\hline 0 & 12.0 & -12.0 & 144.00 & 12.00 \\
\hline 170 & 122.5 & 47.5 & 2256.25 & 18.42 \\
\hline 25 & 46.5 & -21.5 & 462.25 & 9.94 \\
\hline 0 & 14.0 & -14.0 & 196.00 & 14.00 \\
\hline & & & &
\end{tabular}


Texila International Journal of Nursing

Volume 3, Issue 1, Mar 2017

\begin{tabular}{|l|l|l|l|l|}
\hline 0 & 12.0 & -12.0 & 144.00 & 12.00 \\
\hline 160 & 122.5 & 37.5 & 1406.25 & 11.48 \\
\hline 35 & 46.5 & -11.5 & 132.25 & 2.84 \\
\hline 0 & 14.0 & -14.0 & 196.00 & 14.00 \\
\hline 0 & 12.0 & -12.0 & 144.00 & 12.00 \\
\hline 195 & 122.5 & -72.5 & 5256.25 & 42.91 \\
\hline 0 & 46.5 & -46.0 & 2162.25 & 46.50 \\
\hline 0 & 14.0 & -14.0 & 196.00 & 14.00 \\
\hline 0 & 12.0 & -12.0 & 144.00 & 12.00 \\
\hline 25 & 122.5 & -97.5 & 9506.25 & 77.60 \\
\hline 55 & 46.5 & 8.5 & 72.25 & 1.55 \\
\hline 55 & 14.0 & 41 & 1681.00 & 120.07 \\
\hline 60 & 12.0 & 48.0 & 2304.00 & 192.00 \\
\hline 15 & 122.5 & -107.5 & 11556.25 & 94.34 \\
\hline 35 & 46.5 & -11.5 & 132.25 & 2.84 \\
\hline 85 & 14.0 & 71.0 & 5041.00 & 360.07 \\
\hline 60 & 12.0 & 48.0 & 2304.00 & 192.00 \\
\hline Total & & $\mathbf{1 7 0 5 . 1 3}$ \\
\hline
\end{tabular}

Table 10. Chi-square $\left(x^{2}\right)$ test for health care providers and implementation of FANC in hospitals/clinic (Fourth Visit).

\begin{tabular}{|l|l|l|l|l|}
\hline $\mathbf{O}$ & $\mathbf{E}$ & $(\mathbf{O}-\mathbf{E})$ & $(\mathbf{O}-\mathbf{E})^{\mathbf{2}}$ & $\frac{(\boldsymbol{O}-\boldsymbol{E})^{\mathbf{2}}}{\boldsymbol{E}}=\boldsymbol{x}^{\mathbf{2}}$ \\
\hline 195 & 108.2 & 86.8 & 7534.24 & 69.63 \\
\hline 0 & 44.1 & -44.1 & 1944.81 & 44.1 \\
\hline 0 & 26.6 & -26.6 & 707.56 & 26.00 \\
\hline 0 & 16.0 & -16.0 & 256.00 & 16.00 \\
\hline 35 & 108.2 & -73.2 & 5358.24 & 49.52 \\
\hline 165 & 44.1 & 120.9 & 14616.81 & 331.44 \\
\hline 0 & 26.6 & -26.6 & 707.56 & 26.00 \\
\hline 0 & 16.0 & -16.0 & 256.00 & 16.00 \\
\hline 10 & 108.2 & -98.2 & 9643.24 & 89.12 \\
\hline 25 & 44.1 & -19.1 & 364.81 & 8.27 \\
\hline 85 & 26.6 & 58.4 & 3410.56 & 128.22 \\
\hline 75 & 16.0 & -59.0 & 3481 & 217.56 \\
\hline 10 & 108.2 & -98.2 & 9643.24 & 89.12 \\
\hline 30 & 44.1 & -14.1 & 198.81 & 4.51 \\
\hline 80 & 26.6 & 53.0 & 2851.56 & 107.20 \\
\hline 75 & 16.0 & 59.0 & 3481 & 217.56 \\
\hline 195 & 108.2 & 86.8 & 7534.24 & 69.63 \\
\hline 0 & 44.1 & -44.1 & 1944.81 & 44.1 \\
\hline 0 & 26.6 & -26.6 & 707.56 & 26.00 \\
\hline 0 & 16.0 & -16.0 & 256.00 & 16.00 \\
\hline Total & \multicolumn{5}{|l}{} & $\mathbf{3 1 0 0 . 7 1}$ \\
\hline
\end{tabular}

The average calculated chi-square $\left(x^{2}\right)$ using the four visits of FANC is 2740.18

The highest tabulated chi-square $\left(x^{2}\right)$ value is 53.77

Since the Chi-square $\left(x^{2}\right)$ test (calculated) $=2740.18$ is greater than the tabulated value $=53.77$ There is therefore no statistical evidence to accept the null hypothesis (Ho).This means that the health workers have implemented most of the activities under FANC.

Hypothesis four: There are no factors militating against implementation of FANC by health care providers in hospitals/clinics 
Table 11. Chi-square $\left(x^{2}\right)$ test on factors militating against implementation of FANC by health care providers in hospitals/clinics

\begin{tabular}{|l|l|l|l|l|}
\hline $\mathbf{O}$ & $\mathbf{E}$ & $(\mathbf{O}-\mathbf{E})$ & $(\mathbf{O}-\mathbf{E})^{\mathbf{2}}$ & $\frac{(\boldsymbol{O}-\boldsymbol{E})^{\mathbf{2}}}{\boldsymbol{E}}=\boldsymbol{x}^{\mathbf{2}}$ \\
\hline 0 & 20.8 & -20.8 & 432.64 & 20.8 \\
\hline 27 & 80.3 & -53.3 & 2840.89 & 35.38 \\
\hline 70 & 57.5 & 12.5 & 156.25 & 2.72 \\
\hline 98 & 36.3 & 61.7 & 3806.89 & 104.87 \\
\hline 25 & 20.8 & 4.2 & 17.64 & 0.85 \\
\hline 30 & 80.3 & -50.3 & 2530.09 & 31.50 \\
\hline 120 & 57.5 & 62.5 & 3906.25 & 67.93 \\
\hline 20 & 36.3 & -16.3 & 265.69 & 7.32 \\
\hline 15 & 20.8 & -5.8 & 33.64 & 1.68 \\
\hline 100 & 80.3 & 19.7 & 388.09 & 4.83 \\
\hline 30 & 57.5 & -27.5 & 756.25 & 13.15 \\
\hline 50 & 36.3 & 13.7 & 187.69 & 5.19 \\
\hline 20 & 20.8 & -0.8 & 0.64 & 0.03 \\
\hline 150 & 80.3 & 68.7 & 4858.09 & 60.50 \\
\hline 10 & 57.5 & -47.5 & 2256.25 & 39.24 \\
\hline 15 & 36.3 & -21.3 & 453.69 & 12.50 \\
\hline 60 & 20.8 & 39.2 & 1536.64 & 73.88 \\
\hline 115 & 80.3 & 34.7 & 1204.09 & 14.99 \\
\hline 15 & 57.5 & -42.5 & 1806.25 & 31.41 \\
\hline 5 & 36.3 & -31.3 & 979.69 & 26.99 \\
\hline 5 & 20.8 & -15.8 & 249.64 & 12.00 \\
\hline 60 & 80.3 & -20.3 & 412.09 & 5.13 \\
\hline 100 & 57.5 & 42.5 & 1806.25 & 31.41 \\
\hline 30 & 36.3 & -6.3 & 39.69 & 1.09 \\
\hline Total & & & & $\mathbf{6 0 5 . 3 1}$ \\
\hline & & & \\
\hline & & & \\
\hline
\end{tabular}

The calculated chi-square $\left(x^{2}\right)$ value is 605.3

The tabulated chi-square $\left(x^{2}\right)$ value is 25.00

Since the Chi-square $\left(x^{2}\right)$ test (calculated) $=605.31$ is greater than the tabulated value $=25.00$ There is therefore no statistical evidence to reject the null hypothesis (Ho).This means that there is no factors militating against the implementation of FANC in hospitals and clinics in Gboko.

\section{Conclusion}

From the result of this study, health care providers were aware of FANC in their hospitals/clinics. Furthermore, there were no major factors militating against FANC implementation in Benue State. It can be inferred that the hospitals/clinics do not want to implement FANC because of the common that it may affect the revenues that these facilities are getting from the number of visits. Focus antenatal care (FANC) is an evidence-based, goal-directed action, and family-centered, quality-focused approach to antenatal care FANC further promotes health and survival of both mother and child. FANC is an individualized care provided to pregnant woman with emphasis on woman's overall health including the preparation for childbirth and readiness for complications (emergency preparedness). Hence, it should be accepted and implemented for the overall interest of expectant mothers, their unborn child, the family and the society at large as this will go a long way at reducing maternal and infant mortality rate. 
Texila International Journal of Nursing

Volume 3, Issue 1, Mar 2017

\section{Recommendations}

Based on the findings from this present study, the researchers recommend that the government should enforce the full implementation of FANC in all the mother care clinics/hospitals in Benue State. FANC has been found to promote overall women's health and prevent any possible expected complications from conception to child birth. The health care providers should develop awareness on the benefits of FANC that will facilitate an advocacy towards implementation supported by the health care institutions. The implementation of FANC integrated activities such as assessment for referral, and some important screening and tests should be disseminated to ensure complication-free pregnancy and child birth. Health care providers should educate the mothers and support alliance on the importance of FANC as a proven best approach to ANC.

\section{References}

[1]. Agboola, A (2006). Textbook of Obstetrics and Gynaecology for Medical Students. Second Edition. Heinemann Educational Books (Nigeria) Plc

[2]. Agus, Y. and Horiuchi, S. (2012) Factors influencing the use of Antenatal care in Rural West Sumatra, Indonesia. BMC pregnancy and childbirth 2012;12:9 http://doi:10.1186/1471-2393-12-9

[3]. Amosu, A.M, Degun A.M., Thomas, A.M., Olanrewaju, M.F. Babalola Oyerihde A.O., Omeonu, P.E. Ola, O.O., and Nwogwugwu, S. (2011) A Study on the Acceptance and practice of Focused Antenatal care by Healthcare providers in the South-West Zone of Nigeria. Archives of applied Science Research vol 3. Issue 1 pp 484-491.

[4]. Bandac L. (2013) Barriers to utilization of focused Antenatal care among pregnant women in Ntchisi District in Malaria Retrieved from https://tampub.uta.filbitstream/handle/.../gradu06772.pdf?.../

[5]. Boller, C., Wyss, K., Mtasiwa, D. and Tanner, M. (2003) "Quality and comparison of Antenatal care in public and private provider in the united republic of Tanzania. Pubmed Bull World Health Organ 2003; 81:116-122.

[6]. Campbell, O.M and Graham, W.J. (2006) "Strategies of reducing Maternal Mortality: Gelting on with what works pubmed 2006; 368:1284-1299. http://doi:10.1016/So140-6736(06) 69381-1.

[7]. Courad, P., Schmid, G., Tientrebeogo, J., Moses, A., Kirenga, S., Neuhann, F., Muller, O., and Sarker, M. (2011) Compliance with Focused Antenatal Care Services: Do Health Workers in Rural Burkina Faso, Uganda and Tanzania Paform all ANC procedures? Tropical Medicine \&Intenational Health Journal vol.17,issue 3 pp 300-307.http://doi: 10.1111/j.1365-3156.2011.02923.x

[8]. Ekabua J., Ekabua K., and Njoku C. (2011) proposed framework for making focused Antenatal care services Accessible: A review of the Nigerian setting ISRN obstetrics and Gynecology vol 2011:2011:253964.http://doi 10.5402/2011/253964.

[9]. Funmi, A (2014). Reproductive Health for All Ages. Third Edition. Bosem Publishers Nig. Ltd., Akure, Ondo State.

[10]. Gaym, A. (2009) “Antenatal Care” Retrieved from: www.slideshare.net/cdhnmj/antenatal-care24694184.

[11]. Gross, K., Schellenberg, J.A., Kessy, F., Pfeiffer, C., and Obrist, B (2011) Antenatal care in practice: An Exploratory study in Antenatal care clinics in the kilombero Valley South - Eastern Tanzania.

[12]. Marshall, J. E and Raynor, M.D (2014). Myles Textbook for Midwives. Sixteenth Edition. International Edition. Churchill Livingstone, Elsevier

[13]. Shaikh, F. (2016) "Antenatal Care" Retrieved from: www.lumhs.edu.pk/dfhc/ppt/Antenatal_Care.ppt

[14]. UK Essays (2016) Determinants and implications for Focused Antenatal care interventions. Retrieved from: Https:/www.uk essays.com/.../determinants-and-implications-for-focused-antenatalcar.

[15]. United Nations (2009) "the Millennium Development goals Report" retrieved from: http://www.un.org/millenniumgoals

[16]. WHO (2001). WHO Antenatal Care Randomized Trial: Manual for the Implementation of the New Model. Geneva: World Health Organizatio. WHO/RHR/01.30. 


\section{Texila International Journal of Nursing}

Volume 3, Issue 1, Mar 2017

[17]. Yengo, M.L (2009) "Nurses" perception About the Implementation of FANC services in District Facilities of dares Salaam University of South Africa - Ndyomugyenyi, R., Neema, S., and Magnussen, $\mathrm{P}$ (1998) the use of Formal and informal services for Antenatal care and Malaria treatment in rural Uganda. Health policy and planning vol. 13 pp. 94-102. 